\title{
Obesity as a tumour development triggering factor
}

\author{
Agnieszka Budny ${ }^{1, A \oplus}$, Cezary Grochowski ${ }^{2, B} \oplus$, Piotr Kozłowski ${ }^{1, C \oplus}$, Agnieszka Kolak $^{3, D \oplus}$, \\ Marzena Kamińska, ${ }^{4, D \oplus}$, Bożena Budny ${ }^{4, C \oplus}$, Monika Abramiuk ${ }^{5, E \oplus}$, Franciszek Burdan ${ }^{6, F} \oplus$ \\ ${ }^{1}$ Radiotherapy Department, St. John's Cancer Centre, Lublin, Poland \\ ${ }^{2}$ Neurosurgery and Paediatric Neurosurgery Department, Medical University, Lublin, Poland \\ ${ }^{3}$ Pneumology, Oncology and Allergology Department, Medical University, Lublin, Poland \\ ${ }^{4}$ Oncology Department, St. John's Cancer Centre, Lublin, Poland \\ ${ }^{5}$ Clinical Immunology and Immunotherapy Department, Medical University, Lublin, Poland \\ ${ }^{6}$ Human Anatomy Department, Medical University, Lublin, Poland \\ A - Research, concept and design, B - Collection and/or assembly of data, C - Data analysis and interpretation, \\ $D$ - Writing the article, E - Critical revision of article, $F$ - Final approval of article
}

Budny A, Grochowski C, Kozłowski P, Kolak A, Kamińska M, Budny B, Abramiuk M, Burdan F. Obesity as a tumour development triggering factor. Ann Agric Environ Med. 2019; 26(1): 13-23. doi: 10.26444/aaem/100664

\begin{abstract}
Introduction. The overweight and obesity epidemic represents a rapidly growing threat to the health of populations in an increasing number of countries. Nearly one-third of the world's population has excess adipose tissue. Nowadays, obesity occurrence is so common that it is replacing more traditional problems, such as an undernutrition and infectious diseases, as the most significant causes of ill health. If the current trend continues, almost half of the world's adult population will be overweight or obese by 2030.

Objective. The aim of this study is to show the connection between recent trends in body mass index, and the globally changing cancer profile.

State of knowledge. A range of clinical and epidemiological studies have shown the relationship between excess body fat and the most frequently occurring malignancies. Obesity is associated with many cancers, such as: breast, colorectal, liver, lung, kidney, oesophageal, pancreatic, endometrium, ovarian, prostate, thyroid, and gallbladder cancer.

Conclusions. In the light of this information, the study supports the claimed statement that obesity is one of the major health problems of the 21st century. Considering the increase in the number of obese people worldwide, it is necessary to develop a strategy allowing to prevent it. Fighting against unhealthy lifestyle in order to reduce overweight and obesity in society may have an essential impact on decreasing the number of incidences of cancer.
\end{abstract}

\section{Key words}

cancer, malignancy, overweight, carcinogenesis, carcinogenic

\section{INTRODUCTION}

Obesity is a chronic non-communicable disease which is continually spreading further and further [1]. It is defined as an excessive accumulation of fat tissue in body - for men it accounts for over $20 \%$ and for women for over $25 \%$ of total body weight. The majority of the world population lives in countries where overweight and obesity kill more people than underweight. In 2013, an estimated 4.5 million deaths worldwide were caused by overweight and obesity. The most commonly used index rating body mass is the body mass index (BMI). BMI is the ratio of body weight expressed in kilograms to squared height expressed in meters $\left(\mathrm{BMI}=\right.$ body weight $\mathrm{kg} /$ height $\left.\mathrm{m}^{2}\right)$. BMI under $18.5 \mathrm{~kg} /$ $\mathrm{m}^{2}$ indicates underweight, BMI between $18.5-24.9 \mathrm{~kg} / \mathrm{m}^{2}$ indicates normal weight, BMI ranging from $25-29.9 \mathrm{~kg} / \mathrm{m}^{2}$ shows overweight, and BMI over $30 \mathrm{~kg} / \mathrm{m}^{2}$ shows obesity [2]. The way fat tissue is allocated also has an impact on health fat tissue located mainly around the abdomen is a far worse pathological condition for health. A waist circumference (WC) of $102 \mathrm{~cm}$ (40 inches) or more in men, or $88 \mathrm{~cm}$ (35

Address for correspondence: Agnieszka Budny, Radiotherapy Department, St. John's Cancer Center, Lublin, Poland

e-mail: agnieszka.budny@yahoo.com

Received: 24.10.2018; accepted: 11.12.2018; first published: 17.01.2019 inches) or more in women, is associated with health problems. Another helpful measurement is the waist-hip ratio or waistto-hip ratio (WHR). This is the ratio of the circumference of the waist to that of the hips. The normal ratio for women should not exceed 0.85 , and for men 0.9 .

Between 1980 and 2004, in the USA, the number of obese adults doubled (from 15\% to 33\%), whereas the number of obese children tripled (from 6\% to 19\%) [3]. A similar trend is noticeable worldwide [4]. Between 2003 - 2004, the frequency of occurrence of Class 3 obesity (BMI $\geq 40 \mathrm{~kg} / \mathrm{m}^{2}$ ) amounted to $2.8 \%$ among men, and $6.9 \%$ among women [5]. In 2014, an estimated number of obesity cases (considering gender and age) amounted to $10.8 \%$ among men, $14.9 \%$ among women, and $5.0 \%$ among children [6].

Based on a Polish study conducted in Krakow among adolescents aged 14-18 years, it was revealed that the prevalence of overweight and obesity was $10.2 \%$ (boys $10.3 \%$; girls $10.1 \%$ ) and $4.2 \%$ (boys $5.3 \%$; girls $3.3 \%$ ), respectively. Aggregate percentages of obesity and overweight status in this teenage group were $15.6 \%$ males and $13.4 \%$ females [7]. According to Smith et al. [8], should this trend be maintained, by the year $2030,38 \%$ of the world population will be affected by overweight, and another $20 \%$ will be obese. The causeand-effect relationship between obesity occurrence and heart diseases, type 2 diabetes, lipid disorders, obstructive sleep 
apnea, arthritis as well as high blood pressure, is widely documented $[9,10]$. A small percentage of society realizes the influence of obesity on the occurrence of certain types of tumours [11]. According to research conducted by Arnold et al. [12], obesity was a cause of $3.6 \%$ of all tumors worldwide, which, expressed in a number, accounts for 481000 of new cases of cancer disease within only one year.

Obesity is the second most common (after smoking), preventable cause of carcinogenesis. It is classified as a modifiable factor. Should certain habits in society be altered, the number of cancer cases would be decreased. Obesity prevention, as well as an increase in society awareness regarding obesityrelated risks, would contribute to a decrease in the probability of cancer occurrence [13]. Many years ago, obesity was associated with a higher frequency of cancer occurrence, such as: breast, colorectal, uterus, kidney, esophageal, pancreatic, endometrium, ovarian, prostate, thyroid, and gallbladder cancer, as well as head and neck cancer [14].

In 2016, the International Agency for Research on Cancer (IARC) found sufficient evidence to support the association between excess body fat and 13 out of 24 cancer sites: oesophagus (adenocarcinoma), gastric cardia, colon, liver, gallbladder, pancreas, postmenopausal breast, endometrium, ovary, kidney, meningioma, thyroid and multiple myeloma [15]. Oh et al. [16], based on the Korean population, also demonstrated positive dose-dependent relationships with BMI for small-cell lung cancer, non-Hodgkin's lymphoma, and melanoma. With every additional $5 \mathrm{~kg} / \mathrm{m}^{2}$ increase in the BMI, the relative cancer risk increases by 1.3-1.7 fold $[17,18,19]$. Obesity does not appear to have the same effect on all types of cancer. Fat distribution in the body is also important, as central obesity (defined as WC of $\geq 94 \mathrm{~cm}$ for European men and $\geq 80 \mathrm{~cm}$ for European women, with ethnically specific values for other groups) has more harmful effects than gynoid obesity [20].

Likewise, carcinogenic impact is not the same for men and women. On the basis of recent estimates, the obesity-related cancer burden represents up to $9 \%$ of the cancer burden among women in North America, Europe, and the Middle East [21]. Kuriyama et al. [22], during a 9-year follow-up study of THE Japanese population, noticed an interesting risk dependency of cancer occurrence in relation to BMI in the normal range $18.5-24.9 \mathrm{~kg} / \mathrm{m}^{2}$. For women, $\mathrm{RR}=1.04(95 \%$ $\mathrm{CI}=0.85-1.27)$ corresponded to the $\mathrm{BMI}=25.0-27.4 \mathrm{~kg} / \mathrm{m}^{2}$, $\mathrm{RR}=1.29(95 \% \mathrm{CI}=1.00-1.68)$ for those with the BMI = $27.5-29.9 \mathrm{~kg} / \mathrm{m}^{2}$, and $\mathrm{RR}=1.47(95 \% \mathrm{CI}=1.06-2.05)$ for Japanese women with the $\mathrm{BMI} \geq 30.0 \mathrm{~kg} / \mathrm{m}^{2}(\mathrm{p}=0.007)$.

A higher BMI played a particularly important role in the case of colorectal, postmenstrual breast, endometrium, and gallbladder cancer among Japanese women. Moreover, obesity leads to higher cancer-related mortality rate. One study found that current patterns of overweight and obesity in the United States could account for $14-20 \%$ of all deaths caused by cancer [23]. The Class 3 obesity (BMI $\geq 40 \mathrm{~kg} /$ $\mathrm{m}^{2}$ ) increases the risk of dying from all cancers combined by about $52 \%$ in men, and by $62 \%$ in women [23]. A study published by Batty et al. [24], based on a group of London civil servants, proved extensive mortality among obese and overweight people due to rectal, bladder, colon, and liver cancer, as well as leukemia (after considering socio-economic status and physical activity in comparison to people with normal body weight). The occurrence of cancer in relation to body mass has been examined in numerous studies.
The way obesity stimulates tumor development has been researched since the 1930s. Cancer is a disorder with an abnormal regulation of the growth and survival of cells. Fat cells generate many hormones, growth factors, and cytokines that can disrupt regulation of cell growth and survival. The increase in morbidity risk may be explained through a few phenomena occurring among obese people: the increase of insulin level in blood and increased value of insulin-like growth factor (IGF-1) [25], chronic inflammatory condition occurring in people with excessive fat tissue and related to the occurrence of pro-inflammatory cytokines (e.g. interleukin-1, 1L-1; interleukin-6, IL-6; tumor necrosis factor- $\alpha$, TNF- $\alpha$ ) [26] as well as high values of estrogen that is excessively produced by fat tissue [27]. The influence of estrogen on carcinogenesis in breast, ovarian and endometrial cancer has been widely proved. Additionally, overweight/obesity decreases sex hormone binding globulin (SHGB) [28]. Fat cells produce adipokines, which are hormones stimulating or impeding the growth of cells. Leptin is an example of such local hormones, including adiponectin [29]. In animal model studies, the leptin hormone was shown to be beneficial for cancer cell development [30]. Increased insulin level in blood and IGF-1 can be observed among obese people [31]. This condition is also called insulin resistance and it is a pre-diabetes condition [32]. To compensate for insulin resistance, the levels of insulin in the blood rise, leading to chronic hyperinsulinemia. The increased concentrations of circulating insulin induced by adiposity are higher among men than women [33], and men are more prone to abdominal fatness than women [34]. Epidemiological studies as well as in vivo studies have demonstrated that insulin resistance can lead to enhanced tumor growth [35]. It is worth emphasizing that the activity of IGF-1 may stimulate development of vascular endothelial growth factor (VEGF) in tumor cells, which stimulates the further growth of tumor.

According to Gallagher and LeRoith [36], next to type two diabetes, obese people are more prone to colorectal, kidney, prostate, and endometrial uterine cancer. Other possible mechanisms affecting the risk of cancer diseases are altered immune response and oxidative stress. A chronic inflammatory condition, frequently occurring among obese people, may over time lead to the damage of DNA cells, which, consequently, leads to cancer. Some conditions are an example of that, such as Barret's esophagus and esophagitis that may turn into esophageal adenocarcinoma. Obesity is also a risk factor for the occurrence of gall stones, which is related to an inflammatory condition of gallbladder; and may subsequently turn into gallbladder cancer. Randi et al. [37] indicate that gallbladder cancer may be avoided by removing gallbladder and its gallstones and by preventing obesity. In turn, Bishayee [38] indicates that ulcerative colitis or hepatitis, which are also inflammatory diseases of organs, are the cause of liver cancer.

Endometrial cancer. For endometrial cancer, obesity continues to be the strongest risk factor $[39,40]$. There are two types of endometrial cancer to be distinguished: type one, estrogen-dependent, and type two, non-estrogen-dependent, whose clinical course is more aggressive. Setiawan et al. [41] noticed that BMI contributes to a higher risk of the occurrence of endometrial cancer, both of type one and two. Bhaskaran et al. [42] concluded that $41 \%$ of all cases of uterine cancer is related to excessive body weight. According 
to them, a $5 \mathrm{~kg} / \mathrm{m}^{2}$ increase in BMI corresponds to morbidity risk $\mathrm{RR}=1.62$. This data would be concordant with the results of a research group examining the number of cancer cases in the European Union, where they estimated a relationship between obesity and endometrial cancer occurrence to be at the level of 39\% [13]. Renehan et al. [43], on the other hand, have estimated such a risk at the level of $\mathrm{RR}=1.59$ per each $5 \mathrm{~kg} / \mathrm{m}^{2}$ increase in BMI. Similarly, Crosbie et al. [44] in their prospective research analysis have calculated that the overall RR per $5 \mathrm{~kg} / \mathrm{m}^{2}$ increase in BMI was $1.60(95 \% \mathrm{CI}=1.52-1.68)$. The association was stronger in never hormone replacement therapy (HRT) users $(\mathrm{RR}=1.90 ; 95 \% \mathrm{CI}=1.57-2.31)$ than in ever users $(\mathrm{RR}=1.18 ; 95 \% \mathrm{CI}=1.06-1.31)$. Aune et al. [45] were analyzing the relationship between obesity and the age at which excessive weight appeared. What is even more interesting is that they noticed that among younger female patients an increase in BMI is related to higher risk than in the case of the same BMI among older women. In turn, Calle et al. [23] showed over six times higher risk of endometrial cancer morbidity for women with the minimum BMI $40 \mathrm{~kg} /$ $\mathrm{m}^{2}(\mathrm{RR}=6.25 ; 95 \% \mathrm{CI}=3.75-10.42)$.

Ovarian cancer. In 2012, the Collaborative Group on Epidemiological Studies of Ovarian Cancer (CGESOC) published a paper which proved that greater body fatness as measured by BMI and weight are positively associated with the risk of ovarian cancer. A $5 \mathrm{~kg} / \mathrm{m}^{2}$ increase in BMI means a $10 \%$ higher risk among women that have never used HRT during menopause [46]. Similar observations were noted by Purdie et al. [47] from Australia, that there is a significantly increased risk of ovarian cancer with increasing BMI, with women in the top $15 \%$ of the BMI range having an odds ratio (OR) of 1.9 (95\% CI = 1.3-2.6), compared with those in the middle 30\%. Comparatively, Aune et al. [48], after analyzing the scientific literature, calculated the summary RR for a 5 -U increment in BMI was 1.07 (95\% CI $=1.03-1.11)$. The summary RR per 5-U increase in BMI in early adulthood was 1.12 (95\% CI = 1.05-1.20). In 2016, another interesting paper based, on data collected by the International Ovarian Cancer Association Consortium (IOCAC), was published by Dixon et al. [49] They showed in a group of women from Europe, North America and Australia that a higher genetically predicted BMI was associated with increased risk of non-high grade serous ovarian cancers (non-HGSC) (pooled OR $=1.29 ; 95 \% \mathrm{CI}=1.03-1.61$ per 5 units $\mathrm{BMI}$ ) but not HGSC (pooled OR $=1.06 ; 95 \% \mathrm{CI}=0.88-1.27$ ). The association was strongest for low-grade/borderline serous cancers $(\mathrm{OR}=1.93 ; 95 \% \mathrm{CI}=1.33-2.81)$.

Liver cancer. Hepatocellular carcinoma (HHC) accounts for approximately $80 \%$ of primary liver cancers worldwide. It is the fifth most common cause of cancer in men, the seventh in women, and the third leading cause of cancer death [50]. Current evidence strongly indicates that obesity is an HCC risk factor [51, 52, 53]. In 2007, Larsson and Wolk [54], based on academic literature, indicated that overweight and obesity contribute to the more frequent occurrence of liver cancer, and that maintaining normal body weight may partially reduce cancer risk. Nair et al. [55] have also described obesity as an independent factor for hepatocellular carcinoma. HCC develops on liver cirrhosis. In the case of alcoholic liver disease, this risk amounts to $\mathrm{OR}=3.2(95 \% \mathrm{CI}=1.5-6.6)$, whereas in the case of cryptogenic cirrhosis it amounts to
$\mathrm{OR}=11.1(95 \% \mathrm{CI}=1.5-87.4)$. In this paper, obesity was not an independent predictor in patients with hepatitis $\mathrm{C}$ (HCV), hepatitis B (HBV), primary biliary cirrhosis, and autoimmune hepatitis. The higher risk of HCC in obese patients is confined to alcoholic liver disease and cryptogenic cirrhosis. In turn, Chen et al., [56], based on meta-analysis of 25337 cases of primary liver cancer, noticed that excess body weight (EBW), which is overweight and obesity taken together (BMI $\geq 25 \mathrm{~kg} / \mathrm{m}^{2}$ ), is connected to a statistically essential increase in summary relative risk $(S R R=1.48$ for EBW; SRR $=1.83$ for obesity).

A stronger risk of primary liver cancer with EBW was observed for patients with HCV (but not HBV) infection or cirrhosis, compared with the general population. Obese males had a higher risk of primary liver cancer than obese females $(\mathrm{SRR}=1.91$ vs $\mathrm{SRR}=1.55)$. Similar conclusions were reached by Wang et al. [57] who pointed out that patients with HCV or cirrhosis (but not patients with HBV) with EBW had a higher risk of primary liver cancer development than general populations with excess weight. It was proven that the risk of HCC occurrence increased consistently with the increasing level of BMI, and was increased further by the presence of diabetes, suggesting the role of insulin resistance $[58,59]$.

A meta-analysis from Europe, the USA and Asia showed that the risk of developing HCC for overweight individuals was $\mathrm{RR}=1.17(95 \% \mathrm{CI}=1.02-1.34)$, and for obese individuals - $\mathrm{RR}=1.89$ (95\% CI = 1.51-2.36) [60]. An evaluation based on a systematic review of nine cohort studies in the Japanese population indicates a RR of $1.74(95 \% \mathrm{CI}=1.33-2.28)$ for overweight/obese individuals, compared with normal/lowweight individuals [61]. In turn, based on data collected by the Swedish Cancer Registry, it was determined that liver cancer risk was $\mathrm{RR}=3.6(95 \% \mathrm{CI}=2.6-5.0)$ among obese men, compared to those who were thin [62]. Another study indicated that in a cohort of 900,000 American adults the risk of dying from liver cancer was 4.5 times higher in obese men, compared to a control group [63]. This means that obesity contributes to the higher mortality from liver cancers.

Brain cancer. Wolk et al. [64], in examining the Swedish population, estimated the brain tumour standardized the incidence ratio SIR $=1.5(95 \% \mathrm{CI}=1.2-1.9)$ with co-existing obesity. In females, overweight status/obesity was associated with increased risk for overall brain/CNS tumours (pooled $\mathrm{RR}=1.12,95 \% \mathrm{CI}=1.03-1.21$ ), meningiomas (pooled RR $=1.27,95 \% \mathrm{CI}=1.13-1.43$ ), and gliomas (pooled $\mathrm{RR}=1.17$, $95 \% \mathrm{CI}=1.03-1.32$ ). In males, the overweight/obesity status correlated with increased meningioma risk (pooled $\mathrm{RR}=$ $1.58,95 \% \mathrm{CI}=1.22-2.04$ ), whereas the respective association with overall brain/CNS tumour or glioma risk was not statistically significant [65]. The results of a meta-analysis conducted by Shao et al. [66] suggest that it is obesity, and not overweight, that is associated with an increased risk of meningioma. Overall, the combined RRs were 1.12 (95\% CI $=0.98-1.28)$ for overweight and 1.45 (95\% CI $=1.26-1.67)$ for obesity. Similarly, Niedermaier et al. [67], using the normal weight as the reference group, noted that overweight was associated with $\mathrm{RR}=1.21(95 \% \mathrm{CI}=1.01-1.43)$ and obesity with $\mathrm{RR}=1.54(95 \% \mathrm{CI}=1.32-1.79)$ were associated with increased risk of meningioma. In contrast, overweight (RR $=1.06,95 \% \mathrm{CI}=0.94-1.20)$ and obesity $(\mathrm{RR}=1.11,95 \% \mathrm{CI}$ $=0.98-1.27)$ were unrelated to glioma. 
Breast cancer. In 2012, 1.7 million new cases of breast cancer were diagnosed globally, and breast cancer was responsible for nearly 700,000 deaths. Worldwide, the cumulative lifetime risk for women of developing breast cancer between the ages of $0-74$ currently stands at $4.6 \%$. The lifetime risk of dying from breast cancer is $1.4 \%$ [68]. The United States is facing obesity epidemic, in which two out of three women are overweight or obese with $\mathrm{BMI} \geq 25 \mathrm{~kg} / \mathrm{m}^{2}$ [69]. Petrelli et al. [70] calculated breast cancer mortality among American women at $\mathrm{RR}=3.08$ with $\mathrm{BMI}=40 \mathrm{~kg} / \mathrm{m}^{2}$, compared the group with $\mathrm{BMI}=18.5-20.49 \mathrm{~kg} / \mathrm{m}^{2}$. Breast cancer patients who are obese have a higher risk of lymph node metastases and a poorer prognosis than those who are slim. Out of 1,211 patients, those who were obese had a 1.53 higher risk of lymph node metastases, compared to slim patients $(\mathrm{p}=0.02)$. Moreover, in the PgR-negative group, obesity gave a 3.08 times higher risk of lymph node metastases $(p=0.03)$ [71].

On the other hand, epidemiological studies found inverse associations between BMI in childhood and both premenopausal and postmenopausal breast cancer [72, 73]. Most studies report a null or inverse association of obesity with breast cancer risk in premenopausal women [74, 75]. Munsell et al. [76], based on the literature from 1980-2012, concluded that obese women at premenopausal age are less prone to breast cancer with positive estrogen or progesterone receptors than women with normal body weight (the risk of breast cancer with hormone receptor expression is smaller by $20 \%$ ), whereas obese women at postmenopausal age are more prone to this type of cancer than slim women. This risk is higher by $20-40 \%$. Bhaskaran et al. [42], examining a population of women in the United Kingdom in 19872012, similarly estimated that obesity among women at the premenopausal age may have a protective impact against breast cancer (hazard ratio $\mathrm{HR}=0.89$ ). The protective effect of obesity at premenopausal age was also proved by Suzuki et al. in 2009 [77].

Among premenopausal women, excessive BMI was weakly inversely associated with $\mathrm{ER}+\mathrm{PR}+$ tumour. In contrast, there was no overall association with ER-PR- tumours in preor postmenopausal women, nor with ER+PR- tumours in postmenopausal women. Not only have Pierobon and Frankenfeld [78] proved the increased risk of triple negative cancer morbidity among obese women, but they have also concluded that obese premenopausal women are more prone to developing this type of breast cancer than overweight women at the postmenopausal age. According to a study from 2014 , the insulin signaling pathway is a possible mechanism underlying the association between obesity and breast cancer [79]. High concentrations of IGF-I were associated with an increased risk of premenopausal breast cancer $(\mathrm{OR}=1.65$; 1.26-2.08), and high concentrations of IGFBP-3 (Insulinlike growth factor-binding protein 3 ) were associated with increased risk of premenopausal breast cancer $(\mathrm{OR}=1.51$; 1.01-2.27).

Fat tissue is subject to significant alterations in obesity due to extensive accumulation of lipids, which leads to the death of adipose cells and recruitment of macrophages. The state of low grade chronic inflammation is related to the activation of NF-kB (nuclear factor kappa-light-chainenhancer of activated B cells) signaling and elevated levels of aromatase - an enzyme limiting the speed in bio-synthesis of estrogen. It occurs not only in visceral and subcutaneous fat, but also in breast tissue [80]. The relationship of adiposity with increased breast cancer risk in postmenopausal women could, in part, be explained by increases in the serum levels of endogenous sex steroids, notably estradiol, estrone, free estradiol and free testosterone [81].

There are a number of scientific studies proving that an increase in BMI among postmenopausal women results in an increase in developing breast cancer $[82,83]$. A meta-analysis from 2008, published in The Lancet, proved that an increase of $5 \mathrm{~kg} / \mathrm{m}^{2}$ in BMI means an increase of $12 \%$ in breast cancer risk. [43]. A more recent analysis, from 2017, seems to confirm this result - it maintains the relationship between weight gain as an adult and postmenopausal breast cancer among women that do not apply HRT; this risk is determined at the level of $11 \%$ per each $5 \mathrm{~kg}$ gain [84]. In never users of HRT, weight, BMI and hip circumference were positively associated with breast cancer risk [85]. Ritte et al. [86] found that current users of postmenopausal HRT were at an increased risk of ER-PR, as well as ER+PR+ tumours, compared to HRT never users. The association of HRT was significantly stronger in leaner women $\left(\mathrm{BMI} \leq 22.5 \mathrm{~kg} / \mathrm{m}^{2}\right)$ than for more overweight women $\left(\mathrm{BMI} \geq 25.9 \mathrm{~kg} / \mathrm{m}^{2}\right)$ for both types of breast cancer.

It is commonly known that mutation carriers in genes BRCA $1 / 2$ are more prone to develop breast cancer. A paper published in 2011 described a 10-year observation study in which 719 mutation carriers were the subjects, among whom 218 cases of breast cancer were diagnosed. No risk increase among young women was noticed: however, at the postmenopausal age, the risk was estimated to be 1.7-2.1 times higher than among women with normal body weight. The protective impact of maintaining normal body weight observed in the whole population may also reduce the risk among BRCA1/2 mutation carriers [87]. The results from a case-control study of 1073 pairs of women with BRCA mutations indicated that a weight loss of 10 or more pounds among the mutational carriers between the ages 18 - 30 was associated with a decreased risk of developing breast cancer between the ages of $30-40$ years [88].

In 2013, the impact of obesity on the risk of developing cancer at premenopausal stage was differentiated depending on ethnical origins. For each $5 \mathrm{~kg} / \mathrm{m}^{2}$ increase in BMI, it was inversely associated with the risk of premenopausal breast cancer $(\mathrm{RR}=0.95 ; 95 \% \mathrm{CI}=0.94-0.97)$. After stratification by ethnicity, the inverse association remained significant only among Africans $(\mathrm{RR}=0.95 ; 95 \% \mathrm{CI}=0.91-0.98)$ and Caucasians $(\mathrm{RR}=0.93 ; 95 \% \mathrm{CI}=0.91-0.95)$. In contrast, among Asian women, a significant positive association was observed [89]. Suzuki et al. [90] conducted an analysis among Japanese women trying to find relationships in breast cancer risk in a non-Western population. Weight gain after the age of 20 and consequent overweight/obesity were combined risk factors for postmenopausal breast cancer risk. A significantly strong relationship between them was noticed in women over the age of 60. In turn, Keum et al. [91] noted that dynamism, in which a woman gains weight, is a better indicator than BMI - obesity then becomes central, which is shown in the metabolic effects that such a fat tissue is triggering.

According to Polish investigations, with regard to body shape, women with breast cancer present an android type of silhouette with the distribution of fat tissue in the central part of the body. Central obesity increases the risk of developing breast cancer in premenopausal women. However, in postmenopausal women, its effect is neutral [92]. There are also papers based on WHR measurement. Connolly et al. [93] 
indicate that higher WHR is related to an increase in breast cancer risk. Harvie et al. [94] showed the postmenopausal risk of breast cancer reduced by $39 \%$ in women with the smallest waist (compared with women with the largest). Such a standpoint would suggest that avoiding abdominal obesity may reduce morbidity among women. There is also a more direct measure of adiposity, percentage of body fat $(\% \mathrm{BF})$, derived from bioelectrical impedance analysis (BIA), as an indicator variable in relation to risk of breast cancer. Based on a Swedish study patient group living in Malmo, it was found that the percentage of BF appeared to be even stronger predictors of breast cancer than BMI [95]. There is no common consensus and clarity on the association between BMI and breast cancer risk. The risk of death within 5 years from diagnosis is 2.5 greater among obese people compared to slim people [96]. Therefore, the authors of reviews and meta-analysis studies advocate the need to take into account the following factors in future research: differences across race/ethnicity in body build and composition, tumour subtype, receptor status, the most appropriate measure of adiposity, body weight changes throughout lifetime, and determinants of lifestyle [97]. Whether obesity is associated with only postmenopausal breast cancer or with both preand postmenopausal breast cancer is an important public health issue for millions of women with excessive weight [98].

Kidney cancer. Wang and $\mathrm{Xu}$ [99] proved that obese and overweight people are nearly twice as prone to kidney cancer than people with normal weight. In turn, Bhaskaran et al. [42], in an analysis from the same year, estimated the risk related to obesity by $\mathrm{RR}=1.25$. Bergstrom et al. [13], examining the frequency with which obesity-related kidney cancer occurs in the European population, determined that up to $25 \%$ of all cases are connected to excessive fat tissue in the body. On the basis of the conducted meta-analysis, it was estimated that an increase in BMI of $5 \mathrm{~kg} / \mathrm{m}^{2}$ was related to $\mathrm{RR}=1.24$ in men, and $\mathrm{RR}=1.34$ in women [43]. Calle et al. [23] determined the relationship between kidney cancer and RR of obesity as ranging between $1.5-4$, emphasizing that obese women, to a greater extent, are prone to neoplasia of this type of cancer. Similar conclusions were drawn by Dobbins et al. [100], who between 1985 - 2011, conducted the analysis of 98 studies on kidney cancer from 18 countries. On that basis, they calculated RR $=1.57$ in obese men $(95 \%$ $\mathrm{CI}=1.38-1.77)$ and $\mathrm{RR}=1.72$ in obese women $(95 \% \mathrm{CI}=$ 1.58-1.88), compared to people with normal body weight. In turn, Samanic et al. [62] determined the risk of kidney cancer occurrence in obese men living in Sweden at the level of $\mathrm{RR}=1.8(95 \% \mathrm{CI}=1.4-2.4)$. A bigger cancer risk was also faced by people whose BMI increased by $15 \%$ during 6 years of observation, compared to men with stable body weight.

Another independently proved risk factor of kidney cancer among obese people is high blood pressure. Sanfilippo et al. [101] proved a more frequent occurrence of kidney cancer among obese people, regardless of the co-existence of high blood pressure in these people.

Gallbladder cancer. Gallbladder cancer is a common disease which has a poor prognosis and is highly aggressive. The mortality rate is one of the highest among all cancer diseases. It occurs mainly in poorly developed countries and is one of the few cancers that mostly concern women. Obesity contributes to the development of gall stones, and may therefore lead to gallbladder cancer. Li et al. [102] showed that overweight people are characterized by a $20 \%$ higher gallbladder cancer risk, compared to people with normal weight, whereas for obese people this risk is higher by $60 \%$. Considering gender, women are more prone to this type of cancer than men. Renehan et al. calculated the risk ratio with an increase in BMI of $5 \mathrm{~kg} / \mathrm{m}^{2}$ to be at the level of 1.59 for women [43]. In turn, Bhaskaran et al. calculated RR = 1.31 in an analogical situation [42]. Based on the analysis of academic literature from $1966-2007$, index $R R=1.15$ was calculated $(95 \% \mathrm{CI}=1.01-1.30)$ for people struggling with overweight, $\mathrm{RR}=1.66$ (95\% CI $=1.47-1.88)$ for obese people. This relationship was expressed more distinctly among obese women $(\mathrm{RR}=1.88 ; 95 \% \mathrm{CI}=1.66-2.13)$ than among obese men $(\mathrm{RR}=1.35 ; 95 \% \mathrm{CI}=1.09-1.68)$ [103]. Whereas Liu et al., based on 14 cohort studies, calculated the following relative risks of gallbladder cancer compared with the normal weight $\left(\mathrm{BMI}=18.5-24.9 \mathrm{~kg} / \mathrm{m}^{2}\right)$ : for EBW individuals (BMI $\left.\geq 25 \mathrm{~kg} / \mathrm{m}^{2}\right) \mathrm{RR}=1.45$ (95\% CI = 1.30-1.61), for overweight people $\left(\mathrm{BMI}=25-29.9 \mathrm{~kg} / \mathrm{m}^{2}\right) \mathrm{RR}=1.10(95 \% \mathrm{CI}=1.02-1.18)$, and for obese people $\left(\mathrm{BMI} \geq 30 \mathrm{~kg} / \mathrm{m}^{2}\right) \mathrm{RR}=1.69(95 \% \mathrm{CI}$ $=1.54-1.86)$ [104].

Thyroid cancer. Kitahara et al. [105], proved in a pooled research analysis of the occurrence of thyroid cancer among obese people, that a $5 \mathrm{~kg} / \mathrm{m}^{2}$ increase in BMI means a $10 \%$ higher risk of this type of cancer. Moreover, a metaanalysis of academic literature conducted by Renehan et al. in 2008 points out that an increase in BMI of $5 \mathrm{~kg} / \mathrm{m}^{2}$ in men translates into morbidity risk $\mathrm{RR}=1.33$, whereas such a high risk increase has not been noticed among women [43]. In 2015, Ma et al. determined the risk of thyroid cancer at the level of $\mathrm{RR}=1.33$ (95\% CI $=1.24-1.42)$, based on 32 research examinations. When stratified by ethnicity, a significantly elevated risk was observed in Caucasians and in Asians. In the histology subgroup analyses, increased risks of papillary thyroid cancer, follicular thyroid cancer, and anaplastic thyroid cancer were observed.

However, obesity was associated with a decreased risk of medullary thyroid cancer [106]. Xu et al. [107] have also researched thyroid cancer with concurrent obesity. Their research included 1,917 patients (1,360 women and $557 \mathrm{men}$ ) with diagnosed papillary thyroid cancer, and 2,127 patients with no cancer as a controlled group. Data regarding weight and height of patients was taken from 3 independent clinicalcontrolled studies. The authors estimated the following parameters: BMI, fat tissue percentage and body surface area. Odds ratio was calculated in relation to risk of papillary thyroid cancer, corrected by age, gender, race/ethnic origin and place of examination. Higher risk of papillary thyroid risk was determined both among men and women, related to higher body weight, higher BMI, excessive fat tissue and body surface area.

Comparing the risk of papillary thyroid cancer among patients with normal body weight (BMI 18.5-24.9 $\mathrm{kg} / \mathrm{m}^{2}$ ) to overweight people (BMI $25-29.9 \mathrm{~kg} / \mathrm{m}^{2}$ ) and obese people $\left(\mathrm{BMI} \geq 30 \mathrm{~kg} / \mathrm{m}^{2}\right)$ odds ratio was $\mathrm{OR}=1.72$ and $\mathrm{OR}=4.17$, respectively. Based on this data, it can be conclusively stated that the risk of this type of cancer among people with BMI $\geq 25 \mathrm{~kg} / \mathrm{m}^{2}$ is significantly higher. 
Colorectal cancer. There are many studies confirming the impact of obesity on an increase in the risk of colorectal cancer and colon cancer. Furthermore, elevated levels of visceral adipose tissue have been associated with hyperinsulinaemia. Increased circulating insulin levels have been identified as a risk factor for the development of colorectal cancer $[108,109,110]$. In 2013, Ma et al.[111] indicated that obesity increases colorectal cancer risk by about $30 \%$. An increase in the risk was noticeable both in a group of women and men; however, it was much higher among men. Moghaddam et al. [112] established that a $2 \mathrm{~kg} / \mathrm{m}^{2}$ increase in BMI contributes to an increase in colorectal cancer risk of 7\% (4-10\%). For a $2 \mathrm{~cm}$ increase in waist circumference, the risk increased by $4 \%(2-5 \%)$. Schlesinger et al. [113] examined yet another indirect relation - the influence of weight gain on the risk of colorectal cancer. The RR was $1.22(95 \% \mathrm{CI}=1.14-1.30)$ for high body weight gain (midpoint: $15.2 \mathrm{~kg}$ ) compared with stable weight. Each $5 \mathrm{~kg}$ weight gain was associated with a $4 \%$ (95\% CI $=2 \%-5 \%)$ higher risk of colorectal cancer. In 2008, Renehan et al. noticed that a $5 \mathrm{~kg} / \mathrm{m}^{2}$ increase in BMI in men was associated with $\mathrm{RR}=1.24$ of colorectal cancer, whereas in women the relationship between obesity and colorectal cancer was much smaller [43]. Similar results were published the following year. Higher BMI was associated with colon $(\mathrm{RR}=1.24 ; 95 \% \mathrm{CI}=1.20-1.28)$ and rectal $(\mathrm{RR}=1.09 ; 95 \%$ $\mathrm{CI}=1.05-1.14)$ cancers in men, and with colon cancer $(\mathrm{RR}$ $=1.09 ; 95 \% \mathrm{CI}=1.04-1.12$ ) in women [114].

On the other hand, Robsahm et al. [115] calculated RR of adenocarcinoma depending on its location in the large intestine. A positive relationship between BMI and cancer was found for all colorectal subsites, with the most pronounced for the distal colon $(\mathrm{RR}=1.59 ; 95 \% \mathrm{CI}=1.34-1.89)$. For the proximal colon and rectum, the risk estimates were 1.24 (95\% $\mathrm{CI}=1.08-1.42)$ and $1.23(95 \% \mathrm{CI}=1.02-1.48)$, respectively. In 2012, Matsuo et al. [116] conducted a comprehensive analysis based on 8 studies in Japan: Japan Public Health Center-based Prospective Study (JPHC-I), Japan Public Health Centerbased Prospective Study (JPHC-II), Japan Collaborative Cohort Study (JACC), Miyagi Cohort Study (MIYAGI-I), Three-Prefecture Cohort Study in Miyagi (MIYAGI-II), Three-Prefecture Cohort study in Aichi (AICHI), Takayama Study (TAKAYAMA)and Ohsaki Cohort Study (OHSAKI). There were 4,979 morbidity cases among 341,380 analyzed cases. A statistically significant increase in cancer morbidity was noticed at BMI $\geq 27 \mathrm{~kg} / \mathrm{m}^{2}$. Moreover, a linear risk increase was noticed when BMI increased by $1 \mathrm{~kg} / \mathrm{m}^{2}-1.03$ for men and 1.02 for women. Another study, conducted by Parr et al. [117], seems to confirm this relation, based on studies of cohort groups from Asia, Australia and New Zealand, where HR was noted at the level of 1.50 for colon and 1.68 for rectum in people with $\mathrm{BMI} \geq 30 \mathrm{~kg} / \mathrm{m}^{2}$, compared to slim people.

In turn, Larsson and Wolk [118] researched the relationship between colorectal cancer and waist line. Colon cancer risk increased with increasing waist circumference (per each $10 \mathrm{~cm}$ increase $)$ in both men $(\mathrm{RR}=1.33 ; 95 \% \mathrm{CI}=1.19-1.49)$ and women $(\mathrm{RR}=1.16 ; 95 \% \mathrm{CI}=1.09-1.23)$ and with an increasing waist-hip ratio (per each 0.1 unit increase) in both men $(\mathrm{RR}=1.43 ; 95 \% \mathrm{CI}=1.19-1.71)$ and women $(\mathrm{RR}$ $=1.20 ; 95 \% \mathrm{CI}=1.08-1.33$ ). By studying a group of newly diagnosed Korean colon cancer patients, Jeong et al. [119] noted that obese patients tend to have smaller colorectal cancer lesions than those who are non-obese. The size and volume of colorectal cancer, $T$ stage, $M$ stage and serum CEA titer, were inversely correlated with general obesity as reflected by BMI or by the visceral fat volume.

Pancreatic cancer. The worldwide, pancreatic cancer incidence indicator is estimated at 8/100 000 persons/year [120]. The most common type of pancreatic malignant tumour is adenocarcinoma, whereas other slowly-developing neuroendocrine cancers represent an insignificant percentage of a total number of pancreatic cancers diagnosed in people. Both general and abdominal fatness increases pancreatic cancer risk [121, 122]. Genkinger et al. [123] analyzed 14 big studies on the occurrence of pancreatic cancer. They concluded that obesity is a factor that increases the possibility of developing pancreatic cancer by about 1.5 times. In turn, Jiao et al. [124] observed a $6 \%$ increase of pancreatic cancer risk in men and $12 \%$ in women. It was estimated that about $7.8 \%$ of cases of pancreatic cancer among the American population could be prevented if only the individuals maintained normal body weight. In 1998, not only did Silverman et al. [125] note an increase of 50-60\% in pancreatic cancer risk among obese people, but they also drew attention to a greater occurrence of this disease among African-Americans, especially women. Arslan et al. [126] also agree with these conclusions, emphasizing that central obesity is especially dangerous for women in the development of pancreatic cancer. Jee et al. [127], while conducting a similar study in a Korean population, also noticed an increase in pancreatic cancer morbidity among obese women (BMI $\geq 30 \mathrm{~kg} / \mathrm{m}^{2}$ ); however, they did not notice any differences in morbidity among men. In turn, Gapstur et al. [128], examining a moderate employee group from Chicago (96 men and 43 women) noted a relationship between obesity and increase in pancreatic cancer risk only in men.

Very interesting conclusions were drawn by Japanese researchers who examined 110, 792 men and women with regard to the risk of development of pancreatic cancer. Lin et al. [129] noted that the risk for Japanese men aged 20 with BMI $30 \mathrm{~kg} / \mathrm{m}^{2}$ and above, was 3.5 higher. There was no relationship between BMI among women aged 20 and an increase in pancreatic cancer risk in the future. Furthermore, a weight loss of $5 \mathrm{~kg}$ and more among men was related to an increase in morbidity risk, whereas among women it was related to a risk decrease. Risk for women with BMI $27.5-29.9 \mathrm{~kg} / \mathrm{m}^{2}$ at later age was about $60 \%$ higher than for women with BMI $20.0-22.4 \mathrm{~kg} / \mathrm{m}^{2}$; such a correlation was not noted among men. Pancreatic cancer risk among the Japanese population differs depending on gender and time of determining BMI. It was stated that physical activity is not linked to pancreatic cancer morbidity; however, obesity among young men significantly increases this risk. In turn, a study conducted in 2001 in an American population by Michaud et al. allowed them to state that RR amounts to 1.72 for person with minimum BMI $30 \mathrm{~kg} / \mathrm{m}^{2}$, compared to people with BMI less than $23 \mathrm{~kg} / \mathrm{m}^{2}(\mathrm{RR}=1.72 ; 95 \% \mathrm{CI}=1.19-2.48)$ [130]. Larsson et al. [131], based on academic literature from 1966-2006, estimated an average risk of pancreatic cancer $\mathrm{RR}=1.12(95 \% \mathrm{CI}=1.06-1.17)$ for each $5 \mathrm{~kg} / \mathrm{m}^{2}$ increase in BMI. For men it was RR $=1.16(95 \% \mathrm{CI}=1.05-1.28)$, whereas for women $\mathrm{RR}=1.10$ (95\% CI = 1.02-1.19).

There is also an association with diabetes mellitus, a disease connected with obesity and pancreatic tumour. The $\mathrm{RR}$ of pancreatic cancer was demonstrated to be negatively 
associated with the duration of diabetes. This may support a theory that diabetes may be an early manifestation of such a tumour. Among patients with a history of diabetes of at least 5 years, the excess RR of pancreatic cancer was about $50 \%$ lower than in individuals for whom the duration of diabetes was shorter (RR 1.5 vs $2.1 ; \mathrm{p}=0.005)$ [132].

Oesophageal cancer. An increase in abdominal pressure, and thus increase in gastroesophageal junction pressure, which is a predisposing factor to the development of gastroesophageal reflux disease (GERD), and its complications connected to intestinal metaplasia (Barrett's esophagus) are noticed among obese people. Obesity contributes to oesophageal reflux disease, which is symptomized by stomach acid rising up to the oesophagus. As a result of a long-lasting irritation of oesophageal mucosa, prolonged inflammation condition leads to metaplasia, which is a re-construction of normal epithelium into pathological epithelium. This is a direct precancer state, which may turn into adenocarcinoma. According to Singh et al. [133], the development of oesophageal cancer with existing abdominal obesity may be affected through the dependent GERD mechanism, described above, as well as non-dependent GERD. They emphasize that metabolicallyactive fat tissue secretes pro-inflammatory adipocytes, which cause oesophageal mucosa inflammation, and, as a result, a cancer. Forty studies have been conducted, including 18 conducted in the Asian population. Based on these studies, it was concluded that non-dependent GERD mechanism causing cancer is dominant. In neoplasia development, the obesity grade based on BMI is not as essential as the visceral fat that escalates carcinogenesis through hormones secreted by adipocytes.

Chow et al. [134] indicate that high BMI increases the risk of developing oesophageal carcinoma, although it does not contribute to the development of cancer characterized by a different histological type - squamous cell carcinoma. Vaughan et al. also noted the relationship between high $\mathrm{BMI}$ and adenocarcinoma $(\mathrm{OR}=1.9 ; 95 \% \mathrm{CI}=1.1-3.2)$ [135]. Moreover, obesity does not seem to correlate with an increase in the occurrence of squamous cell carcinoma, the risk factors for which include smoking and alcohol consumption [136]. International Barrett's and Esophageal Adenocarcinoma Consortium analyzed 12 studies conducted in North America, Europe and Australia, where 3897 patients with esophageal cancer $(n=1,997)$ or with gastroesophageal cancer $(n=1,900)$ were selected [137]. Extremely obese individuals are up to 4 times more prone to this type of cancer ( $\mathrm{RR}=4.8$ for a $\mathrm{BMI}$ of $40 \mathrm{~kg} / \mathrm{m}^{2}$ or more). Renehan et al. indicate that an increase in BMI of $5 \mathrm{~kg} / \mathrm{m}^{2}$ among men subjects them to an increase in RR related to oesophageal adenocarcinoma of 1.52, whereas RR among women amounted to 1.51 ( $\mathrm{p}<0.0001)$ [43]. Samanic et al., in a group of Swedish men, estimated the risk of oesophageal cancer occurrence to be $\mathrm{RR}=2.7$ (95\% CI $=1.3-5.6)$ [62]. Turati et al. determined increased risk of esophageal and gastric cardia adenocarcinoma among 8,000 people suffering from obesity, compared to people with normal weight. The overall RR was 1.71 (95\% CI $=1.50-1.96)$ for BMI between $25 \mathrm{~kg} / \mathrm{m}^{2}-30 \mathrm{~kg} / \mathrm{m}^{2}$, and $2.34(95 \% \mathrm{CI}=1.95-2.81)$ for BMI $\geq 30 \mathrm{~kg} / \mathrm{m}^{2}$. The continuous RR for an increment of $5 \mathrm{~kg} / \mathrm{m}^{2}$ in BMI was $1.11(95 \% \mathrm{CI}=1.09-1.14)$. The association was stronger for oesophageal adenocarcinoma (RR for BMI $\geq$ $\left.30 \mathrm{~kg} / \mathrm{m}^{2}=2.73,95 \% \mathrm{CI}=2.16-3.46\right)$ than for gastric cardia adenocarcinoma $\left(\mathrm{RR}\right.$ for $\mathrm{BMI} \geq 30 \mathrm{~kg} / \mathrm{m}^{2}=1.93,95 \% \mathrm{CI}=$ $1.52-2.45)$ [138].

Prostate cancer. In prostate cancer, there are several different mechanisms, such as decreased serum testosterone, peripheral aromatization of androgens, insulin resistance, and altered adipokine secretion caused by inflammation, which may precipitate the development of and even cause high-grade prostate cancer [139]. In many studies, it was not possible to prove a higher frequency of the occurrence of prostate cancer among obese people [140]. Giovannucci et al. noticed that neither BMI nor WHR are related to more frequent occurrence of prostate cancer or higher degree of the disease. In 1986-1994, based on 1,369 cancer cases in 47,781 men, postulated that obesity occurring among boys aged $5-10$ years may have a protective impact against disease development in the future $(\mathrm{RR}=0.16 ; 95 \% \mathrm{CI}=0.05-0.54)$ [141]. There have also been other opinions voiced indicating that prostate cancer mortality is related to obesity. Higher pre-diagnostic BMI and plasma C-peptide concentrations were both independent positive predictors of prostate cancerspecific mortality, and men with both factors had the worst outcome [142]. High insulin concentration may promote tumour progression via insulin receptor, and the IGF-I receptor and downstream pathways [143]. During 20 years of observation conducted on a large group of Swedish men $(135,006)$, Andersson et al. [144] analyzed the relationship between obesity and prostate cancer. Within this time, they reported 2,368 cases and 708 deaths related to prostate cancer. They pointed out that obesity was essentially related to mortality increase among these men $(\mathrm{RR}=1.40 ; 95 \% \mathrm{CI}=$ 1.09-1.81). Rodriguez et al. [145], on the other hand, analyzed data related to mortality caused by prostate cancer in the American population. The first study group was subject to profound observation between 1959 - 1972 and the second group between 1982 - 1996. In the first group, the mortality risk for obese people compared to slim men was $\mathrm{RR}=1.27$, whereas in the second group it was $\mathrm{RR}=1.21$ (BMI $\geq 30 \mathrm{~kg} /$ $\left.\mathrm{m}^{2} \mathrm{vs} \mathrm{BMI}<25 \mathrm{~kg} / \mathrm{m}^{2}\right)$. MacInnis and English, in an analysis from 2006 [146], claimed that the overall RR for BMI was 1.05 per each $5 \mathrm{~kg} / \mathrm{m}^{2}$ increment $(95 \% \mathrm{CI}=1.01-1.08)$. For studies that reported results by stage of disease, the RRs were stronger in the case of advanced disease $(R R=1.12$ per each $5 \mathrm{~kg} / \mathrm{m}^{2}$ increment; $\left.95 \% \mathrm{CI}=1.01-1.23\right)$, compared with localized disease $\left(\mathrm{RR}=0.96\right.$ per $5 \mathrm{~kg} / \mathrm{m}^{2}$ increment; $95 \% \mathrm{CI}=$ 0.89-1.03). Similarly, for localized prostate cancer, Discacciati et al. [147] observed an inverse linear relationship with BMI $(\mathrm{RR}=0.94 ; 95 \% \mathrm{CI}=0.91-0.97)$ for every $5 \mathrm{~kg} / \mathrm{m}^{2}$ increase. For advanced prostate cancer, they observed a linear direct relationship with BMI $(\mathrm{RR}=1.09 ; 95 \% \mathrm{CI}=1.02-1.16)$ for every $5 \mathrm{~kg} / \mathrm{m}^{2}$ increase. This meta-analysis indicates that obesity is weakly associated with an increased risk of prostate cancer. High BMI predisposes to more aggressive disease course and bigger mortality [148].

Cao and Ma [149] analyzed study results on the biochemical recurrence of cancer among obese people. In 16 studies which followed 26,479 prostate cancer patients after primary treatment, a $5 \mathrm{~kg} / \mathrm{m}^{2}$ increase in BMI was significantly associated with a $21 \%$ increased risk of biochemical recurrence $(\mathrm{RR}=1.21 ; 95 \% \mathrm{CI}=1.11-1.31)$. Vidal and Freedland [150] found that among Caucasians, obesity was positively associated with high-grade disease $(\mathrm{HR}=1.33 ; 95 \% \mathrm{CI}=0.90-1.97)$, but inversely associated with 
low-grade prostate cancer $(\mathrm{HR}=0.80 ; 95 \% \mathrm{CI}=0.58-1.09)$. Among Negros, however, obesity was positively associated with both low-grade $(\mathrm{HR}=2.22 ; 95 \% \mathrm{CI}=1.17-4.21)$ and high-grade disease $(\mathrm{HR}=1.81 ; 95 \% \mathrm{CI}=0.79-4.11)$. Moreover, although obesity was associated with high-grade disease in both Caucasians and Negros, the association was much stronger in Negros (81\% higher risk) than in white men (33\% higher risk) [151].

Lung cancer. Yang et al. [152] analyzed all reports from EMBASE and PubMed database from 1966-2010 on the subject of the relationship between obesity and lung cancer. The risk of lung cancer development was estimated in groups of patients with overweight and obesity, namely, among people with EBW, compared to data on patients with normal body weight $\left(\mathrm{BMI}=18.5-24.9 \mathrm{~kg} / \mathrm{m}^{2}\right) .20$ cohort studies and 11 controlled clinical studies were analyzed ( 7 population studies and 4 hospital studies). A meta-analysis confirmed a negative correlation of higher BMI with the risk of lung cancer development. The risk of lung cancer development for specific groups was structured as follows: overweight $-\mathrm{RR}$ $=0.74(95 \% \mathrm{CI}=0.68-0.80)$; obesity $-\mathrm{RR}=0.71(95 \% \mathrm{CI}=$ $0.62-0.80)$; excess body weight $-\mathrm{RR}=0.79$ (95\% CI $=0.73-$ $0.85)$. This relationship was noted in both cohort studies: overweight $-\mathrm{RR}=0.78(95 \% \mathrm{CI}=0.72-0.84)$; obesity $-\mathrm{RR}$ $=0.80(95 \% \mathrm{CI}=0.73-0.88)$; excess body weight $-\mathrm{RR}=0.78$ $(95 \% \mathrm{CI}=0.72-0.84)$, as well as in controlled clinical studies: overweight $-\mathrm{RR}=0.68(95 \% \mathrm{CI}=0.57-0.82)$; obesity $-\mathrm{RR}$ $=0.56(95 \% \mathrm{CI}=0.40-0.79)$; excess body weight $-\mathrm{RR}=0.65$ (95\% CI $=0.52-0.81)$.

No statistical differences have been observed in the occurrence of lung cancer among obese men and women, and race-related differences (Asian vs non-Asian). The same relationship has been confirmed in present $(\mathrm{RR}=0.63 ; 95 \%$ $\mathrm{CI}=0.57-0.70)$ and former smokers $(\mathrm{RR}=0.73 ; 95 \% \mathrm{CI}=$ $0.58-0.91)$. The relative risk of lung cancer development among non-smokers was slightly higher than among former and present smokers; however, it was still less than among people with normal body weight $(\mathrm{RR}=0.83 ; 95 \% \mathrm{CI}=0.70-$ $0.98)$.

The presented analysis also shows a smaller risk of developing squamous cell cancer $(\mathrm{RR}=0.68 ; 95 \% \mathrm{CI}=0.58-$ $0.80)$ and adenocarcinoma $(R R=0.79 ; 95 \% \mathrm{CI}=0.65-0.96)$ among people with excess body weight. Summarizing the results of this meta-analysis, it is emphasized that overweight and obesity are protective factors against lung cancer, especially among present and former smokers. Attention is also drawn to the fact that the biological mechanism responsible is not clear.

\section{CONCLUSIONS}

Overweight and obesity, due to their range and prevalence, and due to the cause-effect relationship with a number of diseases, constitute a major health problem for the $21 \mathrm{st}$ century. A range of clinical and epidemiological studies show the relationship between obesity and the most frequently occurring cancers. Considering the increase in the number of obese people worldwide, it is necessary to promptly examine mechanisms linking obesity with an increased risk of cancer development, and to develop a strategy allowing its prevention. Countering an unhealthy lifestyle in order to reduce overweight and obesity in society may have an essential impact on reducing the number of incidences and deaths they cause.

\section{REFERENCES}

1. Koh JC, Loo WM, Goh KL, Sugano K, Chan WK, Chiu WY, et al. Asian consensus on the relationship between obesity and gastrointestinal and liver diseases. J Gastroenterol Hepatol. 2016; 31: 1405-13.

2. World Health Organization. Obesity: preventing and managing the global epidemic: report of a WHO consultation. World Health Organ Tech Rep Ser. 2000; 894: 1-253.

3. Ogden CL, Yanovski SZ, Carroll MD, Flegal KM. The epidemiology of obesity. Gastroenterology. 2007; 132: 2087-102.

4. NCD Risk Factor Collaboration (NCD-RisC). Trends in adult bodymass index in 200 countries from 1975 to 2014: a pooled analysis of 1698 population-based measurement studies with 19.2 million participants. Lancet. 2016; 387: 1377-96.

5. Ogden CL, Carroll MD, Curtin LR, McDowell MA, Tabak CJ, Flegal KM. Prevalence of overweight and obesity in the United States, 19992004. JAMA. 2006; 295: 1549-55.

6. Ng M, Fleming T, Robinson M, Thomson B, Graetz N, Margono C, et al. Global, regional, and national prevalence of overweight and obesity in children and adults during 1980-2013: a systematic analysis for the Global Burden of Disease Study 2013. Lancet. 2014; 384: 766-81.

7. Klimek-Piotrowska W, Koziej M, Hołda MK, et al. Anthropometry and body composition of adolescents in Cracow, Poland. PLoS One. 2015; 10(3): e0122274.

8. Smith KB, Smith MS. Obesity Statistics. Prim Care. 2016; 43: 121-35.

9. Kopelman P. Obesity as a medical problem. Nature. 2000; 404: 635-43.

10. Dixon JB. The effect of obesity on health outcomes. Mol Cell Endocrinol. 2010; 316: 104-8.

11. Vucenik I, Stains JP. Obesity and cancer risk: Evidence, mechanisms, and recommendations. Ann N Y Acad Sci. 2012; 1271: 37-43.

12. Arnold M, Pandeya N, Byrnes G, Renehan PAG, Stevens GA, Ezzati PM, et al. Global burden of cancer attributable to high body-mass index in 2012: a population-based study. Lancet Oncol. 2015; 16: 36-46.

13. Bergstrom A, Pisani P, Tenet V, Wolk A, Adami HO. Overweight as an avoidable cause of cancer in Europe. Int J Cancer. 2001; 91: 421-30.

14. Carroll K. Obesity as a risk factor for certain types of cancer. Lipids. 1998;33:1055-9

15. Lauby-Secretan B, Scoccianti C, Loomis D, Grosse Y, Bianchini F, Straif $\mathrm{K}$, et al. Body Fatness and Cancer--Viewpoint of the IARC Working Group. N Engl J Med. 2016; 375: 794-8.

16. Oh SW, Yoon YS, Shin SA. Effects of Excess Weight on Cancer Incidences Depending on Cancer Sites and Histologic Findings Among Men: Korea National Health Insurance Corporation Study. J Clin Oncol. 2005; 23: 4742-4754.

17. Adami HO, Trichopoulos D. Obesity and mortality from cancer. New Engl J Med. 2003; 348: 1623-4.

18. Sciacca L, Vigneri R, Tumminia A, Frasca F, Squatrito S, Frittitta L, et al. Clinical and molecular mechanisms favoring cancer initiation and progression in diabetic patients Nutr Metab Cardiovasc Dis. 2013; 23: $808-15$.

19. Vigneri P, Frasca F, Sciacca L, Frittitta L, Vigneri R. Obesity and cancer nutrition. Nutr Metab Cardiovasc Dis. 2006; 16: 1-7.

20. Chang SC, Yang WCV. Hyperglycemia,tumorigenesis, and chronic inflammation. Crit Rev Oncol Hematol. 2016;108:146-53.

21. Arnold M, Leitzmann M, Freisling H, Bray F, Romieu I, Renehan A, et al. Obesity and cancer: an update of the global impact. Cancer Epidemiol. 2016;41:8-15.

22. Kuriyama S, Tsubono Y, Hozawa A, Shimazu T, Suzuki Y, Koizumi Y, et al. Obesity and risk of cancer in Japan. Int J Cancer. 2005; 113: 148-57.

23. Calle EE, Rodriguez C, Walker-Thurmond K, Thun MJ. Overweight, obesity, and mortality from cancer in a prospectively studied cohort of U.S. adults. N Engl J Med. 2003; 348: 1625-38.

24. Batty GD, Shipley MJ, Jarrett RJ, Breeze E, Marmot MG, Smith GD. Obesity and overweight in relation to organ-specific cancer mortality in London (UK): findings from the original Whitehall study. Int J Obes (Lond). 2005; 29: 1267-74.

25. Calle EE, Kaaks R. Overweight, obesity and cancer: epidemiological evidence and proposed mechanisms. Nat Rev Cancer. 2004; 4: 579-91.

26. Pietrzyk L, Torres A, Maciejewski R, Torres K. Obesity and Obeserelated Chronic Low-grade Inflammation in Promotion of Colorectal Cancer Development. Asian Pac J Cancer Prev. 2015; 16: 4161-8. 
27. Renehan AG, Zwahlen M, Egger M. Adiposity and cancer risk: new mechanistic insights from epidemiology. Nat Rev Cancer. 2015; 15: 484-98.

28. Kruk J. Lifestyle components and primary breast cancer prevention. Asian Pac J Cancer Prev. 2014; 15: 10543-55.

29. Wąsowski M, Marcinowska-Suchowierska E. The link between obesity and cancer. Post Nauk Med. 2013; 4: 316-25.

30. Barone I, Catalano S, Gelsomino L, Marsico S, Giordano C, Panza S, et al. Leptin mediates tumor-stromal interactions that promote the invasive groth of breast cancer cells. Cancer Res. 2012; 72: 1416-27.

31. Vigneri R, Goldfine ID, Frittitta L. Insulin, insulin receptors, and cancer. J Endocrinol Invest. 2016; 39: 1365-1376.

32. Kahn BB, Flier JS. Obesity and insulin resistance. J Clin Invest. 2000; 106: 473-81.

33. Kaaks R, Lukanova A, Kurzer MS. Obesity, endogenous hormones, and endometrial cancer risk: a synthetic review. Cancer Epidemiol Biomarkers Prev. 2002; 11: 1531-43.

34. Geer EB, Shen W. Gender differences in insulin resistance, body composition, and energy balance. Gend Med. 2009; 356: 60-75.

35. Cohen DH, LeRoith D. Obesity, type 2 diabetes, and cancer: the insulin and IGF connection. Endocr Relat Cancer. 2012; 19: F27-F45.

36. Gallagher EJ, LeRoith D. Obesity and diabetes: The increased risk of cancer and cancer-related mortality. Physiol Rev. 2015; 95: 727-48.

37. Randi G, Franceschi S, La Vecchia C. Gallbladder cancer worldwide: geographical distribution and risk factors. Int J Cancer. 2006; 118: 1591-1602.

38. Bishayee A. The role of inflammation and liver cancer. Adv Exp Med Biol. 2014; 816: 401-35.

39. Beavis AL, Smith AJB, Fader AN. Lifestyle changes and the risk of developing endometrial and ovarian cancers: opportunities for prevention and management. Int J Womens Health. 2016; 8: 151-67.

40. Zhang Y, Liu H, Yang S, Zhang J, Qian L, Chen X. Overweight, obesity and endometrial cancer risk: results from a systematic review and meta-analysis. Int J Biol Markers. 2014; 29: e21-9.

41. Setiawan VW, Yang HP, Pike MC, McCann SE, Yu H, Xiang YB, et al. Type I and II endometrial cancers: have they different risk factors? J Clin Oncol. 2013; 31: 2607-18.

42. Bhaskaran K, Douglas I, Forbes H, dos-Santos-Silva I, Leon DA, Smeeth L. Body-mass index and risk of 22 specific cancers: a population-based cohort study of 5.24 million UK adults. Lancet. 2014; 384: 755-65.

43. Renehan AG, Tyson M, Egger M, Heller RF, Zwahlen M. Body-mass index and incidence of cancer: a systematic review and meta-analysis of prospective observational studies. Lancet. 2008; 371: 569-78.

44. Crosbie EJ, Zwahlen M, Kitchener HC, Egger M, Renehan AG. Body mass index, hormone replacement therapy, and endometrial cancer risk: a meta-analysis. Cancer Epidemiol Biomarkers Prev. 2010; 19: 3119-30.

45. Aune D, Navarro Rosenblatt DA, Chan DS, Vingeliene S, Abar L, Vieira L, et al. Anthropometric factors and endometrial cancer risk: a systematic review and dose-response meta-analysis of prospective studies. Ann Oncol. 2015; 26: 1635-48.

46. Collaborative Group on Epidemiological Studies of Ovarian Cancer. Ovarian cancer and body size: individual participant meta-analysis including 25,157 women with ovarian cancer from 47 epidemiological studies. PLoS Med. 2012; 9: e1001200.

47. Purdie DM, Bain CJ, Webb PM, Whiteman DC, Pirozzo S, Green AC. Body size and ovarian cancer: case-control study and systematic review (Australia). Cancer Causes Control. 2001; 12: 855-63.

48. Aune D, Navarro Rosenblatt DA, Chan DS, Abar L, Vingeliene S, Vieira AR, et al. Anthropometric factors and ovarian cancer risk: a systematic review and nonlinear dose-response meta-analysis of prospective studies. Int J Cancer. 2015; 136: 1888-98.

49. Dixon SC, Nagle CM, Thrift AP, Pharoah PD, Pearce CL, Zheng $\mathrm{W}$, et al. Adult body mass index and risk of ovarian cancer by subtype: a Mendelian randomization study. Int J Epidemiol. 2016; 45: 884-95.

50. El-Serag HB. Epidemiology of viral hepatitis and hepatocellular carcinoma. Gastroenterology. 2012; 142: 1264-73.

51. Scalera A, Tarantino G. Could metabolic syndrome lead to hepatocarcinoma via non-alcoholic fatty liver disease? World J Gastroenterol. 2014; 20: 9217-28.

52. Hung CH, Wang JH, Hu TH, Chen CH, Chang KC, Yen YH, et al. Insulin resistance is associated with hepatocellular carcinoma in chronic hepatitis C infection. World J Gastroenterol. 2010; 16: 2265-71.

53. Seyda Seydel G, Kucukoglu O, Altinbasv A, Demir OO, Yilmaz S, Akkiz $\mathrm{H}$, et al. Economic growth leads to increase of obesity and associated hepatocellular carcinoma in developing countries. Ann Hepatol. 2016; 15: $662-72$.
54. Larsson SC, Wolk A. Overweight, obesity and risk of liver cancer: a meta-analysis of cohort studies. Br J Cancer. 2007; 97: 1005-8.

55. Nair S, Mason A, Eason J, Loss G, Perrillo RP. Is obesity an independent risk factor for hepatocellular carcinoma in cirrhosis? Hepatology. 2002; 36: 150-5.

56. Chen Y, Wang X, Wang J, Yan Z, Luo J. Excess body weight and the risk of primary liver cancer: an updated meta-analysis of prospective studies. Eur J Cancer. 2012; 48: 2137-45.

57. Wang Y, Wang B, Shen F, Fan J, Cao H. Body mass index and risk of primary liver cancer: a meta-analysis of prospective studies. Oncologist. 2012; 17: 1461-8.

58. Donadon V, Balbi M, Zanette G. Hyperinsulinemia and risk for hepatocellular carcinoma in patients with chronic liver diseases and Type 2 diabetes mellitus. Expert Rev Gastroenterol Hepatol. 2009; 3: 465-7.

59. N'Kontchou G, Paries J, Htar MTT, Ganne-Carrie N, Costentin L, Grando-Lemaire V, et al. Risk Factors for Hepatocellular Carcinoma in Patients With Alcoholic or Viral C Cirrhosis. Clin Gastroenterol Hepatol. 2006; 8: 1062-8.

60. Streba LA, Vere CC, Rogoveanu I, Streba CT. Nonalcoholic fatty liver disease, metabolic risk factors, and hepatocellular carcinoma: an open question. World J Gastroenterol. 2015; 21: 4103-10.

61. Tanaka K, Tsuji I, Tamakoshi A, Matsuo K, Ito H, Wakai K, et al Obesity and liver cancer risk: an evaluation based on a systematic review of epidemiologic evidence among the Japanese population. Jpn J Clin Oncol. 2012; 42: 212-21.

62. Samanic C, Chow WH, Gridley G, Jarvholm B, Fraumeni JF Jr. Relation of body mass index to cancer risk in 362,552 Swedish men. Cancer Causes Control. 2006; 17: 901-9.

63. Baffy G, Brunt EM, Caldwell SH. Hepatocellular carcinoma in non-alcoholic fatty liver disease: an emerging menace. J Hepatol. 2012; 56: 1384-91.

64. Wolk A, Gridley G, Svensson M, Nyrén O, McLaughlin JK, Fraumeni JF, et al. A prospective study of obesity and cancer risk (Sweden). Cancer Causes Control. 2001; 12: 13-21.

65. Sergentanis TN, Tsivgoulis G, Perlepe C, Ntanasis-Stathopoulos I, Tzanninis IG, Sergentanis TN, et al. Obesity and Risk for Brain/CNS Tumors, Gliomas and Meningiomas: A Meta-Analysis. PLoS ONE. 2015; 10: e0136974.

66. Shao C, Bai L-P, Qi Z-Y, Hui G-Z, Wang Z. Overweight, Obesity and Meningioma Risk: A Meta-Analysis. PLoS ONE. 2014; 9: e90167.

67. Niedermaier T, Behrens G, Schmid D, Schlecht I, Fischer B, Leitzmann MF. Body mass index, physical activity, and risk of adult meningioma and glioma. Neurology. 2015; 85: 1342-50.

68. Ferlay J, Soerjomataram I, Dikshit R, Eser S, Mathers C, Rebelo M, et al. Cancer incidence and mortality worldwide: Sources, methods and major patterns in GLOBOCAN 2012. Int J Cancer. 2015; 136: E359-86.

69. Matthews SB, Thompson HJ. The Obesity-Breast Cancer Conundrum: An Analysis of the Issues. Int J Mol Sci. 2016; 17: 989.

70. Petrelli JM, Calle EE, Rodriguez C, Thun MJ. Body mass index, height, and postmenopausal breast cancer mortality in a prospective cohort of US women. Cancer Causes Control. 2002; 13: 325-32.

71. Maehle BO, Tretli S, Thorsen T. The associations of obesity, lymph node status and prognosis in breast cancer patients: dependence on estrogen and progesterone receptor status. APMIS. 2004; 112: 349-57.

72. Baer HJ, Colditz GA, Rosner B, Michels KB, Rich-Edwards JW, Hunter DJ, et al. Body fatness during childhood and adolescence and incidence of breast cancer in premenopausal women: a prospective cohort study. Breast Cancer Res. 2005; 356: R314-25.

73. Baer HJ, Tworoger SS, Hankinson SE, Willett WC. Body fatness at young ages and risk of breast cancer throughout life. Am J Epidemiol. 2010; 356: 1183-94.

74. Berstad P, Coates RJ, Bernstein L, Folger SG, Malone KE, Marchbanks $\mathrm{PA}$, et al. A case-control study of body mass index and breast cancer risk in white and African-American women. Cancer Epidemiol Biomarkers Prev. 2010; 19: 1532-44.

75. Cheraghi Z, Poorolajal J, Hashem T, Esmailnasab N, Irani AD. Effect of Body Mass Index on Breast Cancer during Premenopausal and Postmenopausal Periods: A Meta-Analysis. PLoS ONE. 2012; 7: 989.

76. Munsell MF, Sprague BL, Berry DA, Chisholm G, Trentham-Dietz A. Body mass index and breast cancer risk according to postmenopausal estrogen-progestin use and hormone receptor status. Epidemiol Rev. 2014; 36: 114-36.

77. Suzuki R, Orsini N, Saji S, Key TJ, Wolk A. Body weight and incidence of breast cancer defined by estrogen and progesterone receptor status-A meta-analysis. Int J Cancer. 2009; 124: 698-712.

78. Pierobon M, Frankenfeld CL. Obesity as a risk factor for triple-negative breast cancers: a systematic review and meta-analysis. Breast Cancer Res Treat. 2013; 137: 307-14. 
79. Renehan AG, Zwahlen M, Minder C, O’Dwyer ST, Shalet SM, Egger M. Insulin-like growth factor (IGF)-I, IGF binding protein-3, and cancer risk: systematic review and meta-regression analysis. Lancet. 2014; 356: 1346-53.

80. Divella R, De Luca R, Abbate I, Naglieri E, Daniele A. Obesity and cancer: the role of adipose tissue and adipo-cytokines-induced chronic inflammation. J Cancer. 2016; 7: 2346-2359.

81. Rinaldi S, Key TJ, Peeters PHM, Lahmann PH, Lukanova A, Dossus L, et al. Anthropometric measures, endogenous sex steroids and breast cancer risk in postmenopausal women: A study within the EPIC cohort. Int J Cancer. 2006; 118: 2832-39.

82. Emaus MJ, van Gils CH, Bakker MF, Bishchop CN, Monninkhof EM, Bueno-de-Mesquita $\mathrm{HB}$, et al. Weight change in middle adulthood and breast cancer risk in the EPIC-PANACEA study. Int J Cancer. 2014; 135: 2887-99.

83. Mahoney MC, Bevers T, Linos E, Willett WC. Opportunities and strategies for breast cancer prevention through risk reduction. CA Cancer J Clin. 2008; 58: 347-71.

84. Kyrgiou M, Kalliala I, Markozannes G, Gunter MJ, Paraskevaidis E, Gabra $\mathrm{H}$, et al. Adiposity and cancer at major anatomical sites: umbrella review of the literature. BMJ. 2017; 356: j477.

85. Lahmann PH, Hoffmann K, Allen N, van Gils CH, Khaw KT, Tehard $\mathrm{B}$, et al. Body size and breast cancer risk: findings from the European Prospective Investigation into Cancer And Nutrition (EPIC). Int J Cancer. 2004; 111: 762-71.

86. Ritte R, Lukanova A, Berrino F, Dossus L, Tjønneland A, Olsen A, et al Adiposity, hormone replacement therapy use and breast cancer risk by age and hormone receptor status: a large prospective cohort study. Breast Cancer Res. 2012; 14: R76.

87. Manders P, Pijpe A, Hooning MJ, Kluiijt I, Vasen HF, Hoogerbrugge $\mathrm{N}$, et al. Body weight and risk of breast cancer in BRCA1/2 mutation. Breast Cancer Res Treat. 2011; 126: 193-202.

88. Kotsopoulos J, Olopado OI, Ghadirian P, Lubinski L, Lynch HT, Isaacs C, et al. Changes in body weight and the risk of breast cancer in BRCAland BRCA2 mutation carriers. Breast Cancer Res. 2005; 7: R833-43.

89. Amadou A, Ferrari P, Muwonge R, Moskal A, Biessy C, Romieu I, et al. Overweight, obesity and risk of premenopausal breast cancer according to ethnicity: a systematic review and dose-response meta-analysis. Obes Rev. 2013; 14: 665-78.

90. Suzuki S, Kojima M, Tokudome S, Mori M, Sakauchi F, Wakai K, et al. Obesity/weight gain and breast cancer risk: findings from the Japan collaborative cohort study for the evaluation of cancer risk. J Epidemiol. 2013; 23: 139-45.

91. Keum N, Greenwood DC, Lee DH, Kim R, Aune D, Ju W, et al. Adult weight gain and adiposity-related cancers: a dose-response metaanalysis of prospective observational studies. J Natl Cancer Inst. 2015; 107: pii:djv088.

92. Pacholczak R, Klimek-Piotrowska W, Kuszmiersz P. Associations of anthropometric measures on breast cancer risk in pre- and postmenopausal women--a case-control study. J Physiol Anthropol. 2016; 35: 7.

93. Connolly BS, Barnett C, Vogt KN, Li T, Stone J, Boyd NF. A metaanalysis of published literature on waist-to-hip ratio and risk of breast cancer. Nutr Cancer. 2002; 44: 127-38.

94. Harvie M, Hooper L, Howell AH. Central obesity and breast cancer risk: a systematic review. Obes Rev. 2003; 4: 157-73.

95. Lahmann PH, Lissner L, Gullberg B, Olsson H, Berglund G. A prospective study of adiposity and postmenopausal breast cancer risk: The Malmö diet and cancer study. Int J Cancer. 2003; 103: 246-52.

96. Dal Maso L, Zucchetto A, Talamini R, Serraino D, Stocco CF, Vercelli $\mathrm{M}$, et al. Effect of obesity and other lifestyle factors on mortality in women with breast cancer. Int J Cancer. 2008; 123: 2188-94.

97. Kruk J. Overweight, Obesity, Oxidative Stress and the Risk of Breast Cancer. Asian Pac J Cancer Prev. 2014; 15: 9579-86.

98. Anderson GL, Neuhouser ML. Obesity and the Risk for Premenopausal and Postmenopausal Breast Cancer. Cancer Prev Res. 2012; 5: 515-21.

99. Wang F, Xu Y. Body mass index and risk of renal cell cancer: a doseresponse meta-analysis of published cohort studies. Int J Cancer. 2014; 135: $1673-86$

100. Dobbins M, Decorby K, Choi BCK. The Association between Obesity and Cancer Risk: A Meta-Analysis of Observational Studies from 1985 to 2011. ISRN Prev Med. 2013; 680536.

101. Sanfilippo KM, McTigue KM, Fidler CJ, Neaton JD, Chang Y, Fried LF, et al. Hypertension and obesity and the risk of kidney cancer in 2 large cohorts of US men and women. Hypertension. 2014; 63: 934-41.

102.Li L, Gan Y, Li W, Wu C, Lu Z. Overweight, obesity and the risk of gallbladder and extrahepatic bile duct cancers: A meta-analysis of observational studiem. Obesity (Silver Sprong). 2016; 24: 1786-802.
103. Larsson SC, Wolk A. Obesity and the risk of gallbladder cancer: a meta-analysis. Br J Cancer. 2007; 96: 1457-61.

104.Liu H, Zhang Y, Ai M, Wang J, Jin B, Teng Z, et al. Body Mass Index Can Increase the Risk of Gallbladder Cancer: A Meta-Analysis of 14 Cohort Studies. Med Sci Monit Basic Res. 2016; 22: 146-55.

105. Kitahara CM, McCullough ML, Franceschi S, Rinaldi S, Wolk A, Neta $\mathrm{G}$, et al. Anthropometric factors and thyroid cancer risk by histological subtype: Pooled analysis of 22 prospective studies. Thyroid. 2016; 26: 306-18.

106. Ma J, Huang M, Wang L, Ye W, Tong Y, Wang H. Obesity and Risk of Thyroid Cancer: Evidence from a Meta-Analysis of 21 Observational Studies. Med Sci Monit. 2015; 21: 283-91.

107. Xu L, Port M, Landi S, Gemignani F, Cipollini M, Elisei R, et al. Obesity and the risk of papillary thyroid cancer: a pooled analysis of three case - control studies. Thyroid. 2014; 24: 966-974.

108. Kaaks R, Toniolo P, Akhmedkhanov A, Lukanova A, Biessy C, Dechaud $\mathrm{H}$, et al. Serum C-peptide, insulin-like growth factor (IGF)-I, IGFbinding proteins, and colorectal cancer risk in women. J Natl Cancer Inst. 2000;92:1592-600.

109. Yoon YS, Keum N, Zhang X, Cho E, Giovannucci EL. Hyperinsulinemia, insulin resistance and colorectal adenomas: A meta-analysis. Metabolism. 2015;64:1324-33.

110. Schoen RE, Tangen CM, Kuller LH, Burke GL, Cushman M, Tracy $\mathrm{RP}$, et al. Increased blood glucose and insulin, body size, and incident colorectal cancer. J Natl Cancer Inst. 1999; 91: 1147-54.

111. Ma Y, Yang Y, Wang F, Zhang P, Shi C, Zou Y, et al. Obesity and risk of colorectal cancer: a systematic review of prospective studies. PLoS One. 2013; 8: e53916.

112. Moghaddam AA, Woodward M, Huxley R. Obesity and risk of colorectal cancer: a meta-analysis of 31 studies with 70,000 events. Cancer Epidemiol Biomarkers Prev. 2007; 16: 2533-47.

113. Schlesinger S, Lieb W, Koch M, Fedirko V, Dahm CC, Pischon T, et al. Body weight gain and risk of colorectal cancer: a systematic review and meta-analysis of observational studies. Obes Rev. 2015; 16: 607-19.

114. Harriss DJ, Atkinson G, George K, Cable NT, Reilly T, Haboubi N, et al. Lifestyle factors and colorectal cancer risk (1): systematic review and meta-analysis of associations with body mass index. Colorectal Dis. 2009; 11: 547-63.

115. Robsahm TE, Aagnes B, Hjartåker A, Langseth H, Bray FI, Larsen IK. Body mass index, physical activity, and colorectal cancer by anatomical subsites: a systematic review and meta-analysis of cohort studies. Eur J Cancer Prev. 2013; 22: 492-505.

116. Matsuo K, Mizoue T, Tanaka K, Tsuji I, Sugawara Y, Sasazuki S, et al. Association between body mass index and the colorectal cancer risk in Japan: pooled analysis of population-based cohort studies in Japan. Ann Oncol. 2012; 23: 479-90.

117. Parr CL, Batty GD, Lam TH, Barzi F, Fang X, Ho SC, et al. Bodymass index and cancer mortality in the Asia-Pacific Cohort Studies Collaboration: pooled analyses of 424519 participants. Lancet Oncol. 2010; 11: 741-52.

118. Larsson SC, Wolk A. Obesity and colon and rectal cancer risk: a metaanalysis of prospective studies. Am J Clin Nutr. 2007; 86: 556-65.

119. Jeong TG, Kim JW, Lee SY, Park HS, Han HS, Hwang DY. Inverse Correlation between Cancer Size and Abdominal Obesity in Colorectal Cancer Cases. Asian Pac J Cancer Prev. 2016; 17: 4025-30.

120. Raimondi S, Maisonneuve P, Lowenfels AB. Epidemiology of pancreatic cancer: an overwier. Nat Rev Gastroenterol Hepatol. 2009; 6: 699-708.

121. Aune D, Greenwood DC, Chan DSM, Vieira AR, Navarro Rosenblatt DA, Cade JE, et al. Body mass index, abdominal fatness and pancreatic cancer risk: a systematic review and non-linear dose-response metaanalysis of prospective studies. Ann Oncol. 2012; 23: 843-52.

122. Wörmann SM, Algül H. Risk factors and therapeutic targets in pancreatic cancer. Front Oncol. 2013; 3: 282.

123. Genkinger JM, Spiegelman D, Anderson KE, Bernstein L, van den Brandt PA, Calle EE, et al. A pooled analysis of 14 cohort studies of anthropometric factors and pancreatic cancer risk. Int J Cancer. 2011; 129: $1708-17$

124. Jiao L, de Gonzalez AB, Hartge P, Pfeiffer RM, Park Y, Freedman DM, et al. Body mass index, effect modifiers, and risk of pancreatic cancer: a pooled study of seven prospective cohorts. Cancer Causes Control. 2010: 21: 1305-14.

125. Silverman DT, Swanson CA, Gridley G, Wacholder S, Greenberg RS, Brown LM, et al. Dietary and nutritional factors and pancreatic cancer: a case-control study based on direct interviews. J Natl Cancer Inst, 1998; 90: 1710-9.

126. Arslan AA, Helzlsouer KJ, Kooperberg C, Shu XO, Steplowski E, Bueno-de-Mesquita HB, et al. Anthropometric Measures, Body Mass 
Index and Pancreatic Cancer: a Pooled Analysis from the Pancreatic Cancer Cohort Consortium (PanScan). Arch Intern Med. 2010; 170: 791-802.

127. Jee S, Yun J, Park E, Cho ER, Park IS, Sull JW, et al. Body mass index and cancer risk in Korean men and women. Int J Cancer. 2008; 123: 1892-6.

128. Gapstur SM, Gann PH, Lowe W, Liu K, Colangelo L, Dyer A. Abnormal glucose metabolism and pancreatic cancer mortality. JAMA. 2000; 283: $2552-8$.

129. Lin Y, Kikuchi S, Tamakoshi A, Yagyu K, Obata Y, Inaba Y, et al. Obesity, physical activity and the risk of pancreatic cancer in a large Japanese cohort. Int J Cancer. 2007; 120: 2665-71.

130. Michaud DS, Giovannucci E, Willett WC, Colditz G, Stampfer M, Fuchs CS. Physical activity, obesity, height, and the risk of pancreatic cancer. JAMA. 2001; 286: 921-9.

131. Larsson SC, Orsini N, Wolk A. Body mass index and pancreatic cancer risk: A meta-analysis of prospective studies. Int J Cancer. 2007; 120: 1993-8.

132. Huxley R, Ansary-Moghaddam A, Berrington de González A, Barzi F, Woodward M. Type-II diabetes and pancreatic cancer: a meta-analysis of 36 studies. Br J Cancer. 2005; 92: 2076-83.

133. Singh S, Sharma A, Murad M, Buttar NS, El-Serag HB, Katzka DA, et al. Central adiposity is associated with increased risk of esophageal inflammation, metaplasia, and adenocarcinoma: a systematic review and meta-analysis. Clin Gastroenterol Hepatol. 2013; 11: 1399-412.

134. Chow W-H, Blot WJ, Vaughan TL, Risch HA, Gammon MD, Stanford JL, et al. Body mass index and risk of adenocarcinomas of the esophagus and gastric cardia. J Natl Cancer Inst. 1998; 90: 150-5.

135. Vaughan TL, Davis S, Kristal A, Thomas DB. Obesity, alcohol, and tobacco as risk factors for cancers of the esophagus and gastric cardia: adenocarcinoma versus squamous cell carcinoma. Cancer Epidemiol Biomarkers Prev. 1995; 4: 85-92.

136. Freedman ND, Abnet CC, Leitzmann MF, Mouw T, Subar AF, Hollenbeck AR, et al. A prospective study of tobacco, alcohol, and the risk of esophageal and gastric cancer subtypes. Am J Epidemiol. 2007; 165: 1424-33.

137. Hoyo C, Cook MB, Kamangar F, Freedman ND, Whiteman DC, Bernstein L, et al. Body mass index in relation to oesophageal and oesophagogastric junction adenocarcinomas: a pooled analysis from the International BEACON Consortium. Int J Epidemiol. 2012; 41: 1706-18.

138. Turati F, Tramacere I, La Vecchia C, Negri E. A meta-analysis of body mass index and esophageal and gastric cardia adenocarcinoma. Ann Oncol. 2013; 24: 609-17.

139. Parikesit D, Mochtar CA, Umbas R, Hamid AR. The impact of obesity towards prostate diseases. Prostate Int. 2016; 4: 1-6.
140. Kolonel LN. Nutrition and prostate cancer. Cancer Causes Control. 1996; 7: 83-94.

141. Giovannucci E, Rimm EB, Stampfer MJ, Colditz GA, Willett WC. Height, body weight, and risk of prostate cancer. Cancer Epidemiol Biomarkers Prev. 1997; 6: 557-63.

142. Ma J, Li H, Giovannucci E, Mucci L, Qiu W, Nguyen PL, et al. A long-term survival analysis of prediagnostic body mass index, plasma C-peptide concentration, and prostate cancer-specific mortality among men with prostate cancer. Lancet oncol. 2008; 11: 1039-47.

143. Frasca F, Pandini G, Sciacca L, Pezzino V, Squatrito S, Belfiore A, et al. The role of insulin receptors and IGF-I receptors in cancer and other diseases. Arch Physiol Biochem. 2008; 114: 23-37.

144. Andersson SO, Wolk A, Bergstrom R, Adami HO, Engholm G, Englund A, et al. Body size and prostate cancer: a 20 -year follow-up study among 135006 Swedish construction workers. J Natl Cancer Inst. 1997; 89: 385-9.

145. Rodriguez C, Patel AV, Calle EE, Jacobs EJ, Chao A, Thun MJ. Body mass index, height, and prostate cancer mortality in two large cohorts of adult men in the United States. Cancer Epidemiol Biomarkers Prev. 2001; 10: 345-53.

146. MacInnis RJ, English DR. Body size and composition and prostate cancer risk: systematic review and meta-regression analysis. Cancer Causes Control. 2006; 17: 989-1003.

147. Discacciati A, Orsini N, Wolk A. Body mass index and incidence of localized and advanced prostate cancer--a dose-response meta-analysis of prospective studies. Ann Oncol. 2012; 23: 1665-71.

148. Zhang X, Zhou G, Sun B, Zhao G, Liu D, Sun J, et al. Impact of obesity upon prostate cancer-associated mortality: A meta-analysis of 17 cohort studies. Oncol Lett. 2015; 9: 1307-12.

149. Cao Y, Ma J. Body-mass index, prostate cancer-specific mortality and biochemical recurrence: A systematic review and meta-analysis. Cancer Prev Res. 2011; 4: 486-501.

150. Vidal AC, Freedland SJ. Obesity and Prostate Cancer: A Focused Update on Active Surveillance, Race, and Molecular Subtyping. Eur Urol. 2017; 72: 78-83.

151. Barrington WE, Schenk JM, Etzioni R, Arnold KB, Neuhouser ML, Thompson IM Jr, et al. Difference in Association of Obesity With Prostate Cancer Risk Between US African American and Non-Hispanic White Men in the Selenium and Vitamin E Cancer Prevention Trial (SELECT). JAMA Oncol. 2015; 1: 342-9.

152. Yang Y, Dong J, Sun K, Zhao L, Zhao F, Wang L, et al. Obesity and incidence of lung cancer: a meta-analysis. Int J Cancer. 2013; 132: 1162-1169. 